resurgence or of neo-Nazism. . . AntiSemitism, although a factor, is, relatively speaking and in consideration of past history, not much more prevalent in Germany than elsewhere." If the author's discovery that not all Germans deserve praise, while a minority deserve criticism, enables him to call Germany "schizophrenic," one wonders which country or people in the world is so exclusively composed of democratic and unprejudiced saints that it could escape Mr. Dornberg's psychiatric diagnosis.

\section{New York City}

Berlin-Pivot of German Destiny. Translated and edited by Charles B. Robson. Pp. vi, 233, xvi. Chapel Hill: University of North Carolina Press, 1960. \$5.00.

This book represents an excellent translation of a series of lectures delivered in the summer of 1959 at the Otto Suhr Institute of the Free University of Berlin. To the reader intent upon learning more about Berlin itself than about the crisis generally identified with it, this should be a most welcome source. Rarely, these days, does one find in Western literature adequate reference to the inner substance of the problem: the historic significance of the city, its people, their hopes and aspirations, their rights. Instead, one is bombarded with references to the rights of the free world and the strategic requirements of the Cold War. This book, in diverse ways, graphically demonstrates that the problem has not only ideological and strategic, but also ordinary human propositions--that the city lives, breathes, that it has a significant past which entitles it to a future.

So much has been made of the equation Prussianism-Militarism-Nazism. But this book reminds us that it was the city of Berlin, capital of Prussia, where "the cult of Germanism and extreme anti-Semitism simply could not find the response . . . that those who exercised the power wished." We are reminded that it was in Berlin that the National Socialist power failed to crack the republican, democratic front in the election of March 1933, in spite of the fact that Hitler had already set in motion the police-state apparatus.
Other chapters trace the split of the city and the developments which made it the important issue that it is today. "Berlin as a Socio-Political Problem" examines critically the social and political implications of the Soviet-proposed isolation of Berlin from the West. The consequences of submission to Soviet pressure are subjected to sharp analyses. What will the future bring? Berlin's beloved and heroic mayor, the late Ernst Reuter, proclaimed in 1947: "The idea of unity [of Germany] is a question of life and death for us here in Berlin, without which we have in the long run no justification for existence." What are the possible consequences of Khrushchev's design? Berlin becomes "a small, weak democracy," compelled to accept "the tutelage of that power that is willing to ease its poverty with alms." In the event that the city becomes separated from the West, only the Soviet Union remains to provide the alms. Perhaps such a book tends to be frustrating, with its vexatious implications; but then Berlin is one of the most vexatious issues between East and West, a legal monstrosity made up of ordinary human beings-and with a history and a reputation far brighter than that of the country of which it has been the symbol for so long.

\section{University of Michigan}

\section{Henry L. Bretton}

FRIEDA WUNDERLICH. Farm Labor in Germany, 1810-1945: Its Historical Development Within the Framework of Agricultural and Social Policy. Pp. xv, 390. Princeton, N. J.: Princeton University Press, 1961 . $\$ 8.50$.

The problem of farm labor in Germanyhistorically one of Germany's great social and economic problems-is given comprehensive treatment in Professor Wunderlich's book. What makes this book especially valuable is the fact that it is not a mere compilation of statistical data on wage rates or employment figures. Rather, the author has chosen to treat the problem of German farm labor in its historical, sociological, and political setting. In doing this, she cuts across Germany's rapid industrial development period during the 